\title{
Evaluation of Turkish Teacher Candidates' Usage of Complex Sentences Containing "ki" Conjunction in Turkish
}

\author{
Osman Uyanik \\ Correspondence: Osman Uyanik, A. K. Education Faculty, Necmettin Erbakan University, Konya, Turkey.
}

Received: March 25, 2019

doi:10.11114/jets.v7i6.4166

\author{
Accepted: April 25, $2019 \quad$ Online Published: April 30, 2019 \\ URL: https://doi.org/10.11114/jets.v7i6.4166
}

\begin{abstract}
The purpose of this study is to evaluate the Turkish teacher candidates' usage of Turkish complex sentences with "ki" conjunction, which are one of the most commonly used sentence patterns in Turkish.

The Turkish language has been interacting with different languages for centuries. There are two types of "ki" conjunctions in Turkish. One of them originated from Turkish and the other one was transferred from Persian to Turkish. There is a difference between the "ki" conjunction taken from Persian language and the one which originated from Turkish language. With this research, it is aimed to determine whether students use these two different "ki" conjuctions in their sentences correctly or not. While the "ki" conjunction which was transferred from Persian to Turkish is used for making description sentences, the "ki" conjunction belonging to Turkish is used to make cause-effect sentences.

In this study, a number of Turkish teacher candidates were asked to write compositions containing sentences with "ki" conjunction. The study group consisted of 11 female and 9 male Turkish Teacher Candidates. Data were collected through qualitative research methods and analyzed by document analysis and descriptive analysis.

According to the research results the "ki" conjunction used in sentences by Turkish teacher candidates do not conform to the sentence structure of Persian, but do conform to the sentence structure of Turkish. As a result, it can be said that Turkish teacher candidates should use sentences with "ki" conjunction by taking this difference into consideration.
\end{abstract}

Keywords: Turkish Teacher Candidates, syntax, complex sentences, complex sentence with "ki"

\section{Introduction}

Turkish teacher candidates should know the features of Turkish language very well. Although some toughts are expressed by making more than one sentence in Semitic and Indo-European Languages, the same thoughts can be expressed by just one sentence in Turkish with the help of using participles, gerunds and predicative verbs. The sentences containing gerunds and predicative verbs are classified as simple sentences by some linguists because they are not justified by non-finite verbal forms or gerundials (Karahan, 2004).

The "ki", which is one of the coordinating conjunctions was first seen after the Uyghur period and used in sentences with a connective task. These types of complex sentences have phrases both before and after the conjunction "ki". When the sentences established by using conjunction "ki" are examined in different periods of Turkish, it can be seen that most of the sentences are suitable for the Turkish sentence structure. The main clause in the sentence structure of Turkish is the part following the section of "ki" conjunction. The part before the "ki" conjunction also declares judgment but this is a subordinate clause because it explains the cause of the main phrase.

In sentences that are connected with "ki", the main clause maybe both before and after the "ki" conjunction. This situation can also be explained as the "ki" cunjunction in Persian and the "kim" conjunction in Turkish, and they can be used interchangeably. Previously, the "kim" conjunction belonging to Turkish language was used to connect sentences just like "takı", "baslayu" and "yämä" connecting words in order to make compound sentences. The "ki" conjunction used in Persian compound sentences has also entered into Turkish in the time. Because of the similarity in shape, these two connecting words have begun to be used interchangeably. Therefore, in accordance with the structure of the Persian syntax, the main clause is seen before the "ki" conjunction in some sentences and according to the structure of Turkish syntax, the main clause is seen after the "ki" conjunction in some sentences (Eckmann, 1995; Eckmann, 1996).

As seen in the above sentences, the Turkish "ki" and the Persian "ki" have been used at the same time since the ancient times. The location of the main clause varies due to similarity in shape. It can be understood whether the conjunction is 
Turkish or not from the meaning of the sentence. The "ki" in the reason-result sentences is the word of Turkish itself. There are also sentences made using this conjunction. The main clause follows "ki" in these sentences and it complies with the Turkish syntax.

There are differences between the complex sentences with "ki" conjunctions which are taken from Persian and the ones originated from Turkish. While complex sentences with "ki" conjunction establish statement sentences in Persian, the complex sentences with "ki" conjunction establish cause-effect sentences in Turkish. The main clause is in the sentences that are connected to the the complex sentences with "ki" conjunction which establishes cause and effect phrases complies with the Turkish sentence structure. With this research, it is aimed to determine whether students use these two different complex sentences with "ki" conjunctions correctly in their sentences. Therefore, the research question was determined as follows;

"How do Turkish teacher candidates use the "ki" conjunction in their compositions?"

\section{Method}

\subsection{Research Model}

The method used in the research was descriptive phenomenology, which is among the qualitative research models. Phenomenology means understading the core or the main idea of the subject. Even though phenomenologic studies do not reveal exact and generalizable results as for the nature of qualitative research methods, they provide the chance to analyze the event in depth (Tavşanli and Akaydin, 2017). "Ki" conjuctions in complex sentences of Turkish teacher candidates were analyzed by examining their written expressions.

\subsection{Study Group}

In this research, 20 students studying in the 4th grade of the Turkish Teaching Department, Education Faculty, Necmettin Erbakan University in the 2018-2019 academic year participated in the study. Of the purposeful sampling methods, the convenience sampling method was used. The convenience sampling method is a selection of samples from people that are volunteers and suitable for the research and easy to access (Gravetter and Forzano, 2012). Demographic information of the participants is shown in Table 1.

Table 1. Demographic information of the participants

\begin{tabular}{lllll}
\hline Grade level & \multicolumn{2}{c}{ Gender } & \multicolumn{2}{c}{ Total } \\
& Female Male & f & $\%$ \\
\hline 4 th grade & 11 & 9 & 20 & 100 \\
& $\% 55$ & $\% 45$ & & \\
\hline
\end{tabular}

When the Table 1 is examined, it can be seen that 55\% of (11 people) the participants were female while $45 \%$ (9 people) were male teacher candidates. The coding of the Turkish teacher candidates was as follows:

S: Student, F: Female, M: Male.

\subsection{Data Collection and Analysis}

In this study, the Turkish teacher candidates were asked to write a composition containing complex sentences with "ki" conjunction. They were allowed to choose their topic freely. They were given an hour to write their composition and were told that they could cite quotes from important writers and poets of Turkish literature.

Data were collected through qualitative research methods and analysed by document analysis and descriptive analysis. Document analysis is the analysis of written materials that contain information on the topic or fact intended to be researched (Yildirim and Simsek, 2008). Turkish teacher candidates' compositions containing complex sentences with "ki" conjunction were analyzed. Expert opinions were consulted in the analysis of data.

\section{Results}

Some of the examples of the sentences and citations from other authors containing complex sentences with "ki" conjunction written by Turkish teacher candidates in their compositions are as follows:

"Annem o kadar çok çalışıyordu ki onu zor görüyordum." (My mother was working so hard that I could hardly see her) (S3F)

"Tanıyanlar bilir ki, Yahya Kemal ile beraber olmak, onu dinlemek bir zevktir." (Those who know Yahya Kemal know that it is a pleasure to be with him or to listen to him) (S5M- author: A. Hamdi Tanpınar)

"Mefharet'in yuvarlak etli yüzü o kadar şişiyor ve kızarıyordu ki platin saçları ağarmış gibi görünüyordu." (The round fleshy face of Mefharet was so swelled and blushed that her platinum hair looked gray) (S10F-author: Peyami Safa) 
"Resimleri öyle güzeldi ki beğenmeyen hiçkimse yoktu." (Her pictures were so beautiful that there was no one who didn't like them) (S6M)

"Denizle yaşayan Roma, bir zamanlar bu korsanlardan o kadar yıldı ki Pompei'yi beş yüz gemi, yüz yirmi bin yaya, binlerce süvari ile buralarda büyük bir sefere çıkardı." ("Once upon a time, Rome, who lived with the sea, was tired of pirates so much that he sent Pompei on a cruise around with five hundred ships, one hundred and twenty thousand infantrymen and thousands of cavalrymen.") (S8F- author: Falih Rık1 Atay)

"Hiç görmüyordu ki renkleri farkedebilsin." (She couldn’t see at all, so she couldnt notice the colors.) (S7F)

Analysis of the sentences:

Many of the researchers agree that the sentences established with the "ki" conjunction do not conform to the Turkish syntax. However, they do not explain why the clause coming after the connector in some sentences containing the conjunction "ki" is the main clause and this conforms to the Turkish syntax.

"Tanıyanlar bilir ki, Yahya Kemal ile beraber olmak, onu dinlemek bir zevktir."

\section{(Main Clause) (Subordinate Clause)}

Taking the sentence above into consideration, when the "ki" conjunction is removed and the sentence is reestablished, it becomes as follows (Karahan, 2004).

The word "bilir" coming before "ki" in the clause with the "ki" conjunction will go to the end of the sentence without "ki" conjunction. Therefore the sentence with "ki" conjunction does not fit with Turkish sentence formation.

Mefharet'in yuvarlak etli yüzü o kadar şişiyor ve kızarıyordu ki platin saçları ağarmış gibi görünüyordu.

(Main Clause).............. .........(Subordinate Clause)...........

Taking the sentence above into consideration, when the "ki" conjunction is removed and the sentences is reestablished, it becomes as follows (Karahan, 2004).

"Mefharet’in yuvarlak etli yüzü o kadar şiştiği ve kızardığı için platin saçları ağarmış gibi görünüyordu."

Although the "ki" conjunction is removed, there is no change in the sentence formation. The reason-result clause established here complies with the Turkish sentence formation. The main clause depends, even if there is a "ki" conjuntion or not, on the final judgment. As used herein the "ki" conjunction is the "kim" connecting word in old Turkish. Since the "ki" conjunction here is of Turkish origin, the sentence was established in accordance with the Turkish syntax.

When the sentence, "Denizle yaşayan Roma, bir zamanlar bu korsanlardan o kadar yıldı ki Pompe'yi beş yüz gemi, yüz yirmi bin yaya, binlerce süvari ile buralarda büyük bir sefere çıkardı.", taken from Falih Rıfkı Atay is analyzed according to main clause and subordinate clause, we can see the following (Karahan, 2004)

"Denizle yaşayan Roma, bir zamanlar bu korsanlardan o kadar yıldı / ki /

(Subordiante Clause)

(Conjunction)

Pompe’yi beş yüz gemi, yüz yirmi bin yaya, binlerce süvari ile buralarda büyük bir sefere çıkardı.” (Main Clause)

This phrase here is a cause-effect clause. The subordinate clause comes before the "ki" conjunction. The main clause is is located after the conjunction "ki". If we re-establish sentence by removing the "ki" conjunction, the main clause and subordinate clause do not change.

Reason-Result Sentences Established with the "ki" Conjunction in Persian:

As in Turkish, the reason-result sentences are established with both a reason preposition and the connecting word "ki" in Persian. In Turkish and Persian sentences with a reason-result expression, the main clause and the subordinate clause are in different places. The main clause comes after "ki" conjunction in Turkish but comes before "ki" conjunctin in Persian. We examined the main and subordinate clauses in some sample sentences from Divan of Hafiz.

Bemey seccâde rengîn kun geret pîr-i mugân gûyed/ Ki sâlik bîhaber nebved zi râh u
(Main Clause)
(Subordinate Clause)

resm-i menzilhâ (Hafiz eş-Şirazi, 2010)

If Your Pîr says, "Paint your prayer rug with wine," listen to him for such a traveller is not unaware of the trace and the path of the destination.

(Main Clause)

(Subordinate Clause) 


\section{Discussion}

The purpose of this study is to evaluate the usage of Turkish complex sentences with "ki" conjunction by Turkish teacher candidates. According to the findings of the research, the usege of Turkish complex sentences with "ki" conjunction by Turkish teacher candidates show that all the sentences in Turkish were taken from Persian. Consequently, when the sentences were examined, it was determined that the conjunction "ki" did not come before the main clause in the reason-result sentences like in Persian. According to these data, it can be stated that Turkish teacher candidates should use the sentences containing "üm", "chi" and "üm" by taking this distinction into consideration. Otherwise, their written statements will not be at the desired level. In Yildiz and Ceran's (2016) research, it was determined that Turkish teacher candidates made mistakes in the sentence syntax. In the study of Çamurcu (2011), it was found out that the use of these sentences was low in written statements of Turkish teacher candidates.

The conjunction "ki" connects one sentence to another in today's Turkish and it establishes relationships within the framework of meanings such as description, sort, comparison, reason-result and purpose (Karahan, 2004). In these sentences with "ki" conjunction, there are sentences on either side of the conjunction. One of these sentences is the main clause and the other is the subordinate clause. The main clause and the subordinate clause are determined by removing the "ki" conjunction from the sentence. When the "ki" conjunction is removed, the last part is the main clause and the first part is the subordinate clause.

Complex sentences with the main clause at the beginning and the subordinate clause at the end do not conform with the Turkish sentence syntax. The "ki" conjunction in these sentences was taken from Persian. It is not suitable for the sentence structure of Turkish since it was transferred from another language - Persian. Because of the existence of these types of sentences in Turkish, many researchers think that all sentences with "ki" conjunction entered Turkish with a foreign language influence. Muharrem Ergin describes the sentences made compound using "ki" conjunction as compound sentences with foreign origin because this case is not normal for Turkish language. He also states that the "ki" conjunction in these sentences is the "ki" in Persian and the "kim" in Turkish, and the sentences built with either of them are not compatible with Turkish (Ergin, 2008).

Karahan (2004) expresses that the effect of Persian is seen in the cases where the main clause comes before the conjunction in sentences established with "ki" conjunction.

Ozkan, Toker and Deniz (2016) pointed out that "ki" conjunction was taken from Persian and the main clause comes before the "ki" conjunction because it was adapted from Persian sentence structure to Turkish, and in some sentences the main clause comes after the "ki" conjunction.

Bozkurt (2017) also expresses this conjunction does not comply with the syntax rules of Turkish because it entered our language from Persian, and both this conjunction and this type of sentence entered our language from Persian. As a result it is unfamiliar to our language in terms of structure.

Turkish sentences had a simple sentence structure until the period of Köktürk. Translation works emerged because of religious changes in Turks. Translation works did not only influence Turks, but the sentence structure of translated languages affected Turkish as well. One of these changes occurred in complex sentences established using connecting words. Complex sentences were created in the first translation works with the connecting words already existing in Turkish. Translation of Arabic and Persian works has replaced these connecting words with adapted conjunctions. One of these conjunctions is the "ki" conjunction that entered our language from Persian.

The first translation of the "ki" conjunction in Persian was encountered with the "kim" conjunction in Turkish. In the later periods, the "kim" connecting word in Turkish started to be used together with the "ki" connecting word in Persian. The use of these two connectors has caused the words to resemble each other in shape. Nowadays, both cunjunctions are shaped as "ki". Because of this similarity, many language researchers are of the opinion that this case is suitable for the sentence structure of Persian but it is not suitable for the sentence structure of Turkish. However, there is a difference between the "ki" conjunction taken from Persian language and the one coming from Turkish language. Whereas the conjunction "ki", transferred from Persian, is used to make explanation sentences, the conjunction "ki" in Turkish is used to make sentences of cause and effect. In complex sentences with "ki", informing reason-result situations, made in accordance with Turkish sentence structure, the main clause is at the end of the sentence. Cause and effect sentences are established with "ki" conjunctions in Persian just like in Turkish. In these sentences, the main clause comes before the "ki" conjunction, which is in accordance with the Persian sentence structure. The claim which has been accepted so far is that "All the sentences with "ki" in Turkish were taken from Persian." However, that's not true. Because the main clause in Turkish cause and effect sentences does not come before "ki" conjunction, but the main clause comes before the "ki" conjunction in the statement sentences containing "ki" conjunction in Persian.

With this study, it can be said that Turkish teacher candidates who should use the language effectively are obliged to 
know the characteristics of "leri", "ki", "erek" which passed from Persian to Turkish, and use the related sentences more diligently. In the study of Ylldiz (2016), it was stated that Turkish teacher candidates should use the language carefully.

\section{References}

Bozkurt, F. (2017). Türkiye Türkçesi (Dilbilgisi-Anlatım), Konya: Eğitim Yayınevi.

Çamurcu, D. (2011). Yükseköğrenimine yeni başlayan Türkçe eğitimi bölümü öğrencilerinin yazma becerilerinin incelenmesi. Selçuk Üniversitesi Türkiyat Araştırmaları Dergisi, 1(29), 503-518.

Eckmann, J. (1995). (Yayına haz. Semih Tezcan, Hamza Zülfikar), Nehcü'l- Feradis Uştmahlarnıng Açuq Yolı Metin Tıpkı Basım, Ankara: Türk Dil Kurumu Yayınları.

Eckmann, J. (1996). (Çev: Osman fikri Sertkaya), Harezm, Kıpçak ve Çağatay Türkçesi Üzerine Araştırmalar, Ankara: Türk Dil Kurumu Yayınları.

Ergin, M. (2008). Türk Dil Bilgisi, İstanbul: Bayrak Basım Yayım Tanıtım.

Gravetter, J. F., \& Forzano, L. B. (2012). Research methods for the behavioral sciences (4th Edition). USA: Linda Schreiber-Ganster.

Hafız eş-Şirazi, Şemseddin Muhammed Hafız eş-Şîrazî (ö. 792/1390), Divân-1 Hafız bâ Şerh-1 Ebyât (Şerh eden: Nahîd Ferşad Mehr), İntişârât-1 Gencîne, Tahran, 1388 hicri şemsi/2010 miladi.

Karahan, L. (2004). Türkçede Söz Dizimi, Ankara: Akçağ Yayınları.

Ozkan, A., Toker, M., \& Aşçı, U. D. (2016). Türkiye Türkçesi Söz Dizimi, Konya: Palet Yayınları.

Tavşanli, Ö. F., \& Akaydin, B. B. (2017). Sinif öğretmenlerinin bakiş açisiyla sosyal medya okuryazarliği. Uluslararasi Sosyal Araştirmalar Dergisi, 10(48), 517-528. https://doi.org/10.17719/jisr.2017.1522

Yıldırım, A., \& Şimşek, H. (2008). Qualitative research methods in the social sciences, Ankara: Seçkin Publication.

Yıldız, D., \& Ceran, D. (2016). Türkçe öğretmeni adaylarının yazılı sınavlarda yaptıkları dil yanlışları. Eğitim Bilimlerinde Yenilikler ve Nitelik Arayışı E Kitap, 1057-1072. https://doi.org/10.14527/9786053183563.064

Yıldız, D. (2016). Türkçe Öğretmeni Adaylarının Hazırlıklı Konuşmalarındaki Söz Varlıkları. Milli Eğitim Dergisi, 45(210), 411-424.

\section{Copyrights}

Copyright for this article is retained by the author(s), with first publication rights granted to the journal.

This is an open-access article distributed under the terms and conditions of the Creative Commons Attribution license which permits unrestricted use, distribution, and reproduction in any medium, provided the original work is properly cited. 